\title{
Systemic toxic reaction due to multiple honeybee stings in equine: Case report
}

\author{
[Reação tóxica sistêmica devido a múltiplas ferroadas de abelha em equino: relato de caso] \\ J.H. Fonteque ${ }^{1}$, R.P. Mendes ${ }^{2}$, A.F. Souza ${ }^{2}$, M.C.S. Granella ${ }^{2}$, J. Schade ${ }^{3}$, \\ M.S. Casa $^{3}$, L.A. Yonezawa ${ }^{1}$, J. Volpato ${ }^{1}$ \\ ${ }^{1}$ Universidade do Estado de Santa Catarina - Lages, SC \\ ${ }^{2}$ Aluno de graduação - Universidade do Estado de Santa Catarina - Lages, SC \\ ${ }^{3}$ Aluno de pós-graduação - Universidade do Estado de Santa Catarina - Lages, SC
}

\begin{abstract}
Accidents caused by insects of the Hymenoptera are rarely described in large animals. The attacks caused by honeybee (Apis mellifera) may cause severe consequences and its intensity changes according to the number of stings. Local and systemic reactions can occur, including progression to death. This report describes a case of honeybee attack on an equine, which took place in the city of Lages, in the state of Santa Catarina, Brazil. In the clinical assessment the horse showed apathy, anorexia, head and pectoral edemas, dyspnea, icteric mucosa, increased mandibular lymph nodes and darkened urine. The blood count showed anemia and serum biochemical tests suggested, muscular and hepatic lesions. The urinalysis test indicated hemoglobinuria and increased clotting time. Treatment included lactate Ringer's solution fluid therapy, furosemide, promethazine, corticosteroids and 20\% mannitol solution. Hot and cold compresses were applied alternately on areas with edema. There was a satisfactory response to treatment and the animal was discharged after 30 days in veterinary hospital. The description of honeybee sting accidents in large animals is important because of the evolution that can lead to death. The early approach associated with appropriate treatment, avoiding the worsening of the lesions is fundamental for the recovery of the patient.
\end{abstract}

Keywords: Apis mellifera, intoxication, poison

\section{RESUMO}

Os acidentes causados por insetos da ordem Hymenoptera são raramente descritos em grandes animais. Os ataques provocados por abelhas (Apis mellifera) causam consequências graves, e sua intensidade varia de acordo com a quantidade de ferroadas. Reações locais a sistêmicas podem ocorrer, incluindo a evolução para a morte. Este relato descreve um caso de ataque por abelhas em equino, ocorrido no município de Lages, SC. No exame clínico, o equino apresentava apatia, anorexia, edema de cabeça e região peitoral, dispneia inspiratória, mucosas ictéricas, linfonodos mandibulares aumentados e urina de coloração marrom-escura. O hemograma evidenciou anemia hemolítica, e os exames de bioquímica sérica sugeriram lesão muscular e lesão hepática. A urinálise demonstrou hemoglobinúria, e o tempo de coagulação apresentava-se aumentado. Como tratamento, foram administrados solução de ringer com lactato, furosemida, prometazina, corticosteroides e solução de manitol a 20\%. Compressas quentes e frias foram aplicadas alternadamente sobre as áreas de edema. Houve adequada resposta ao tratamento instituído e o animal recebeu alta hospitalar após 30 dias de internamento. A descrição de casos de acidentes por picadas de abelhas em grandes animais é importante devido à evolução, que pode levar à morte. A abordagem precoce associada ao tratamento adequado, evitando o agravamento das lesões, é fundamental para a recuperação do paciente.

Palavras-chave: Apis mellifera, intoxicação, veneno

Recebido em 3 de maio de 2017

Aceito em 29 de agosto de 2017

*Autor para correspondência (corresponding author)

E-mail: rubeens.mendes@hotmail.com 


\section{INTRODUCTION}

Accidents caused by insects of the order Hymenoptera occur frequently with humans (Langley and Morrow, 1997; Langley, 2005) and with domestic animals, mainly dogs (Schimidt and Hassen, 1996), with limited reports in the scientific literature describing cases involving horses.

In Brazil, honeybee (Apis mellifera), wasps (subfamily Polistinae) and bumblebee (Bombus spp.) attacks are common (Cardoso et al., 2008). Africanized honeybees originated by the crossbreeding of European and African honeybees, were introduced in Brazil with the intention of increasing honey production (Mello et al., 2003).

These accidents are important in veterinary medicine, since the Hymenoptera have an inoculator apparatus (sting) attached to venom glands (Vetter et al., 1999). Apitoxin, or honeybee poison, is essentially a mixture of low molecular weight peptides, biogenic amines, proteins of high allergenic potential as melittin and mainly the enzymes phospholipase A2 and hyaluronidase (Cardoso et al., 2008). Clinical manifestations in domestic animals are related to the amount of stings that the animal is subjected to, ranging from hypersensitivity reactions to a single sting (allergic reactions) to poisoning by a few stings (local toxic reaction) or poisoning by multiple stings (toxic systemic reactions). Individual sensitivity also influences clinical conditions. Therefore, allergic reactions can occur with only one sting in a sensitive animal and may not occur with multiple stings in other animals (Cardoso et al., 2008). Systemic toxic reactions caused by massive honeybee attacks are primarily characterized by typical dermatological changes caused by histamine (Vetter et al., 1999). Besides that, other symptoms such as vomiting, diarrhea, and signs of anaphylactic shock were observed in dogs (Schimidt and Hassen, 1996). In addition, respiratory distress due to acute respiratory distress syndrome (ARDS) can be observed (Walker et al., 2005). Cases of Rhabdomyolysis (França et al., 1994) and hemolytic crisis in dogs (Wysoke et al., 1990; Noble and Armstrong, 1999) have also been reported.
The objective of this study is to report the case of a horse that developed systemic toxic reaction due to multiple honeybee stings, which occurred in the municipality of Lages, located in the state of Santa Catarina, Brazil.

\section{CASUISTRY}

Five hours after being attacked by a honeybee swarm, a 3.5-year-old, mixed breed female equine, weighing $290 \mathrm{~kg}$, was sent for clinical care to the Hospital de Clínicas Veterinárias (HCV) of the Centro de Ciências Agroveterinárias (CAV) belonging to the Universidade do Estado de Santa Catarina (UDESC), in Lages.

Physical examination revealed apathy, anorexia, pyrexia $\left(39.0^{\circ} \mathrm{C}\right)$, tachypnea $(100$ breaths $/ \mathrm{min})$ with inspiratory dyspnea, tachycardia (80bpm), icteric mucous membrane, bilateral mandibular lymph adenomegaly, extensive head edema, mainly on eyelids and snout (Figure 1), edema on pectoral region and blackened urine (Figure 2).

Laboratory blood count tests and serum biochemistry tests showed anemia (corpuscular volume: $20 \%$ ), leukocytosis by neutrophilia with a shift to the left, hyperfibrinogenemia $(900 \mathrm{mg} / \mathrm{dl})$, and increased serum activity of aspartate aminotransferase (AST: 1669.20U/L), creatine kinase (CK: 324.9U/L), gammaglutamyltransferase (GGT: 19.1U/L) and lactate dehydrogenase (LDH: 3.395U/L) enzymes. The urinalysis test indicated hemoglobinuria with negative myoglobin screening and an increase in clotting time (19 minutes). Sinus tachycardia was also observed in the electrocardiographic examination.

As an initial part of the treatment, a therapy with intravenous fluids was administered. The therapy comprised lactated Ringer's solution (35 Liters) and furosemide administration $(0.5 \mathrm{mg} / \mathrm{kg}, \mathrm{IV}$, SID, for three days), promethazine $(0.4 \mathrm{mg} / \mathrm{kg} \mathrm{IV}$, single application) and hydrocortisone $(4 \mathrm{mg} / \mathrm{kg}$, IV, single application). Afterwards, dexamethasone $(0.1 \mathrm{mg} / \mathrm{kg}$, IV, SID, for eight days) and $20 \%$ mannitol solution (IV) were applied. To assist in edema control, warm and cold thermal compresses were applied for five minutes on and off over the snout, eyelids, and breast regions. During the initial period of 
hospitalization, the horse developed pneumonia characterized by pyrexia $\left(39.0^{\circ} \mathrm{C}\right)$ and fine crackles at pulmonary auscultation. This condition was treated with benzathine penicillin (40.000IU/kg, MI, administered every 48 hours for three days).
After seven days in veterinary hospital, there was a reduction of the edema in the snout, eyelids and chest regions, improvement of respiratory condition and the appetite returned to normal. Urine color progressed gradually to normal and the animal was discharged after 30 days of hospitalization. Skin necrosis developed on the spots where the animal was stung (Figure 3).

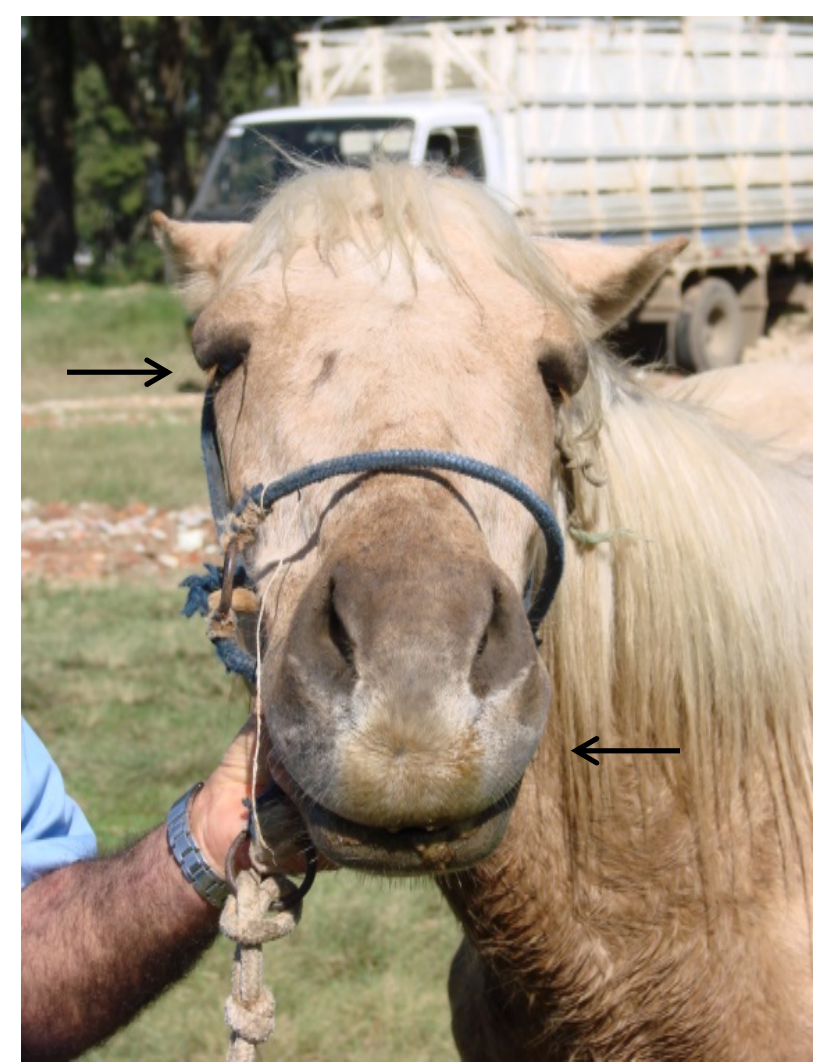

Figure 1. A 3.5-year-old mixed breed female equine, presenting edema in the region of the head, mainly eyelids and snout (arrows) caused by venom inoculated by multiple honeybee stings.

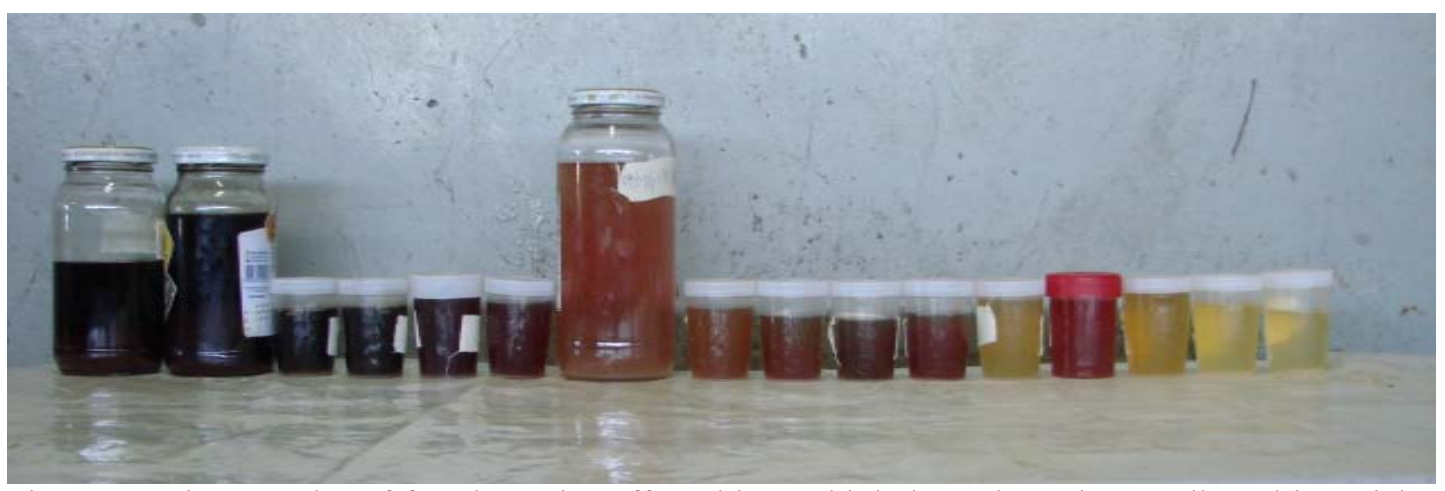

Figure 2. Urine samples of female equine affected by multiple honeybee stings, collected in serial way. From left to right, the evolution from the blackened coloration at the time of hospitalization (hemoglobinuria) to the clear pale-yellow color observed in the last vial at the $10^{\text {th }}$ day. 


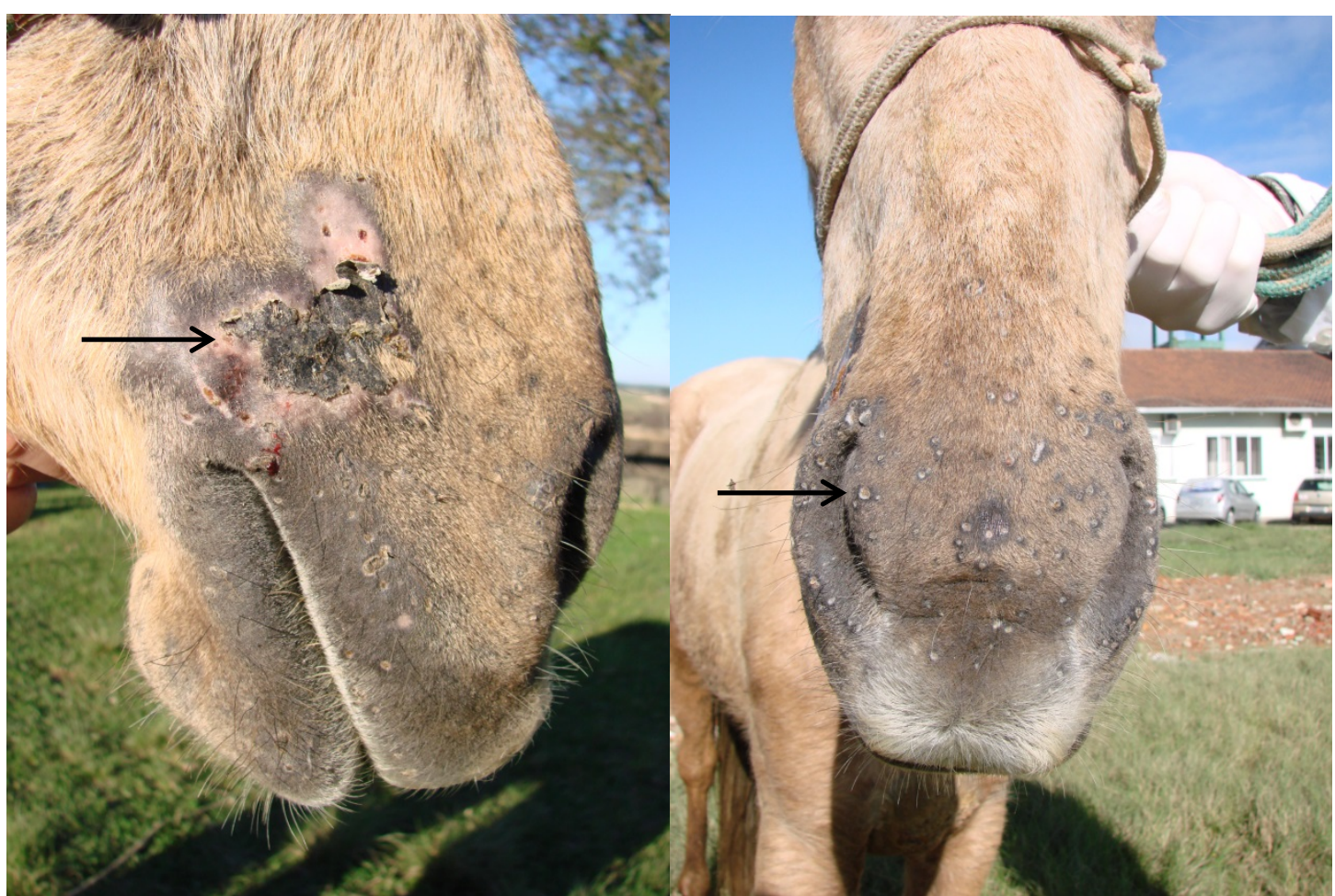

Figure 3. A) A 3.5-year-old mixed breed female equine, presenting sites of skin necrosis in the caudal dorsal regions of the labial commissure (arrow) B) Skin necrosis on the places where the horse was stung by multiple honeybees (arrow).

\section{DISCUSSION}

The diagnosis of systemic toxic reaction caused by multiple honeybee stings was established based on the anamnesis in association with clinical and laboratory findings. The diagnosis of systemic toxic reaction could be erroneously confused with an allergic reaction. However, the high poison absorption and the evidence of multiple bee stings are important to distinguish both. Nevertheless, overlap between the toxic effects and hypersensitivity to poison may have occurred. Accidents resulting from massive honeybee attacks on horses are rarely registered in the literature. Nonetheless, these cases are critical and may be fatal (Sakate, 2008).

The clinical signs were characterized mainly by edema in the eyelid, snout and pectoral regions, by icteric mucous membranes and by hemoglobinuria, which are related to the poison toxicity. The edemas located on the face and chest of the animal derive from the peptideinduced mast cell degranulation, which releases histamine, increasing the capillary permeability and therefore causing local edema (Cardoso et al., 2008). Icteric mucosa and hemoglobinuria occurred as a result of the intravascular hemolysis caused by phospholipase A2 in synergy with melittin, which compromised the erythrocyte cell membrane integrity (Cardoso et al., 2008). Melittin is the precursor of signs of inflammation, especially pain and pyrexia, both systemic and on the places where the honeybee poison was injected. Besides that, melittin has hemolytic, cardiotoxic and cytotoxic potential (Sakate, 2008). The inspiratory dyspnea can be related to a possible glottal edema or due to acute respiratory distress syndrome (ARDS) (Walker et al., 2005). The signs previously reported corroborate with those described by Schimidt and Hassen (1996) in dogs that suffered bee attacks.

During the hospitalization period, complementary laboratory tests were carried out sequentially to follow clinical evolution. Erythrogram tests revealed hemolytic anemia, which, in this case, occurs due to the high hemolytic potential of the honeybee poison. Hemolysis is caused by a lesion on the erythrocyte membrane, resulting in a decrease in 
the number of circulating erythrocytes, characterizing a hemolytic anemia (Sakate, 2008). This finding was similar to that reported by Fighera et al. (2007) in dogs.

Major findings in leucogram tests were leukocytosis by neutrophilia with left upper shift and lymphopenia, corroborating with Sakate (2008). However, eosinopenia can also be detected (Sakate, 2008). According to Breyer (1980), hyperfibrinogenemia occurs in response to local or systemic inflammation caused by melittin, the main active component of apitoxin.

When evaluating urea and creatinine concentrations, values suggesting renal function failure were not found. In the Hepatic Function Panel tests there was an increase in the serum activity of AST and GGT enzymes, suggesting hepatic injury. The determination of serum LDH enzyme activity acts as a marker of hemolysis. Therefore, the increase in the serum activity of this enzyme in the present report, can be related to hemolytic anemia (Kaneko et al., 1997). An increase of the serum activity of the CK enzyme, indicative of muscle lesion was also observed (Sakate, 2008).

Although CK is a specific enzyme to determine muscle damage, it is essential to perform a simultaneous evaluation of CK and AST, due to the difference between active and non-active lesions, which vary according to the half-life of the enzymes. Continual increase in $\mathrm{CK}$ indicates active muscle damage, and elevated AST values with subsequent $\mathrm{CK}$ decline indicate non-active muscle injury (Kaneko et al., 1997). Serum levels of CK and AST, could suggest that the increased serum activity of these enzymes occurred because of possible rhabdomyolysis due to the myotoxic potential of apitoxin (Schimidt and Hassen, 1996). Urinalysis test presented hemoglobinuria, which can be attributed to the destruction of erythrocytes by poison and the deposit of pigment in the urine, leading to a dark color characterized by blackened urine (Cardoso et al., 2008). In addition, the hemoglobin associated to apitoxin can pile up in the renal tubular epithelium, causing an acute tubular necrosis and consequently an acute renal failure (ARF) (Wysoke et al., 1990; Noble and Armstrong, 1999). However, in the present report, there was no evidence of clinical and laboratory signs of
ARF. An important point to consider, is the differentiation between hemoglobinuria and hematuria, since, according to Schmidt and Hassen (1996), hematuria may be late a clinical manifestation found in humans.

The electrocardiographic exam presented sinus tachycardia due to the high sympathetic tone caused by fever and anemia (Fregin, 1992), and due to the apitoxin toxic potential. Mellitin and phospholipase A2 are mainly responsible for the poison cardiotoxic effect, along with tachycardia and hypotension. When massive bee attacks take place, death may follow quickly due to cardiotoxicity (Schimidt and Hassen, 1996).

According to Schimidt and Hassen (1996), the treatment aims to minimize the deleterious effects caused by apitoxin. These effects are proportional to the number of stings in relation to the live weight of the animal. An early removal of stings would make an important step, since the poison continues to be injected into the patient after the attack (Sakate, 2008). In this study, it was not possible to visualize the presence of stings due to the hair covering and the intense edema.

The treatment applied in this case was important for its favorable evolution. Constant medical monitoring and therapy with Ringer's lactate solution were introduced in order to maintain the blood volume, to prevent secondary kidney damage and mainly to provide sustenance, ensuring total elimination of the poison.

Promethazine is an antihistamine that acts to control the effects caused by the release of histamine (Sakate, 2008). The use of corticosteroids as an anti-inflammatory is useful to reduce the inflammatory signs, such as pain, heat and edema caused by the action of the melitin present in the poison (Sakate, 2008). The furosemide is a fast and long-acting diuretic that assists in the elimination of apitoxin and alongside with mannitol it helps to decrease the edema caused by the inflammation at the sting locations. Moreover, the application of hot and cold thermal compresses alternately at the sting spots, has the function of reducing edema and preventing the evolution of the inflammatory process. Skin necrosis on the locations where the animal has been stung is related to the nonremoval of the stings, which were hidden during 
the inspection due to severe edema and hair covering.

\section{CONCLUSION}

Reporting massive bee attacks in equines is of great importance and making the correct clinical assessment of the animal affected is essential. Systemic toxic reaction associated with bee poisoning may involve multiple organs and systems and can progress quickly causing severe consequences. Therefore, early identification of the clinical condition allows the implementation of emergency treatment, which reduces the progression of the lesions and is crucial for patient recovery.

\section{REFERENCES}

CARDOSO, J.L.C.; FRANÇA, F.O.S.; WEN, F.H. et al. Animais peçonhentos no Brasil. Biologia, clínica e terapêutica dos acidentes. 2.ed. São Paulo: Sarvier, 2008. 568p.

FIGHERA, R.; SOUZA, T.; BARROS, C. Acidente provocado por picada de abelhas como causa de morte de cães. Cienc. Rural, v.37, p.590-593, 2007.

FRANÇA, F.O.; BENVENUTI, L.A.; FAN, H.W. et al. Severe and fatal mass attacks by "killer" bees (Africanized honey bees - Apis mellifera scutellata) in Brazil: clinicopathological studies with measurement of serum venom concentrations. Q. J. Med., v.87, p.269-282, 1994.

FREGIN, G.F. Medical evaluation of the cardiovascular system. Vet. Clin. N. Am. Equine Pract., v.8, p.329-346, 1992.

KANEKO, J.J.; HARVEY, J.W.; BRUSS, M.L. Appendixes. In: _ . (Eds.). Clinical biochemistry of domestic animals. 5.ed. London: Academic Press, 1997. p.885-906.
LANGLEY, R.L. Animal-related fatalities in the United States an update. Wilderness Environ. Med., v.16, p.67-74, 2005.

LANGLEY, R.L.; MORROW, W.E. Deaths resulting from animal attacks in the United States. Wilderness Environ. Med., v.8, p.8-16, 1997.

MELLO, M.H.S.H.; SILVA E.A.; NATAL, D. Abelhas africanizadas em área metropolitana do Brasil: abrigos e influências climáticas. Rev. Saúde Pública, v.37, p.237-241, 2003.

NOBLE, S.J.; ARMSTRONG, P.J. Bee sting envenomation resulting in secondary immunemediated hemolytic anemia in two dogs. Journal of the American Veterinary Medical Association, v.214, n.7, p.1021, 1999

SAKATE, M. Zootoxinas. In: SPINOSA, H.S.; GÓRNIAC, S.L.; PALERMO-NETO J. (Eds.). Toxicologia aplicada à medicina veterinária. São Paulo: Manole, 2008. p.209-255.

SCHIMIDT, J.O.; HASSEN, L.V.B. When africanized bees attack: what your clients should know. Vet. Med., v.10, p.923-928, 1996.

VETTER, R.S. et al. Mass envenomations by honey bees and wasps. West. J. Med., v.170, p.223-227, 1999.

WALKER, T. et al. Imaging diagnosis: acute lung injury following massive bee envenomation in a dog. Veterinary Radiology \& Ultrasound, v.46, n.4, p.300-303, 2005.

WYSOKE, J.M. et al. Bee sting-induced haemolysis, spherocytosis and neural dysfunction in three dogs. J. S. Afr. Vet. Assoc., v.61, p.29-32, 1990. 